\title{
'N PROGRAM OM GEHALTE-WERKLEWE VAN PSIGIATRIESE VERPLEEGKUNDIGES TE BEVORDER
}

\author{
B Schoonwinkel, M Muller en H Klopper
}

\begin{abstract}
The aim of this study was to describe guidelines for a personal and professional development programme to facilitate the quality of work-Lfe experienced by psychiatric nurses in a hospital. An explorative and descriptive research design with a qualitative research orientation was employed. The study was divided into three phases. In phase one the needs, desires and expectations of psychiatric nursing in a hospital nursing service were explored and described. In phase two the factors in a nursing service which influence the quality work-life of nurses, were explored and described. Consequently, the last phase of the study was conducted, being inferrred from data of phases one and two which lead to the conceptual framework upon which the guidelines and programme are based. A personal and professional development programme for psychiatric nurses to facilitate quality of work-life experienced, consisting of three parts, was described to enclose aspects of the psychiatric nurse's internal and external environments, as well as patterns of interaction between the internal and extemal environments.
\end{abstract}

\section{UITTREKSEL}

Die doelstelling met hierdie studie was om riglyne vir 'n persoonlike en professionele ontwikkelingsprogram te beskryf, ten einde die gehalte-werklewe wat deur psigiatriese verpleegkundiges aan 'n hospitaal ervaar word, te bevorder. ' $n$ Verkennende en besknwende navorsingsontwierp, met 'n kwalitatiewe navorsingsoriëntasie, is nagevolg. Die studie is in drie fases verdeel. In die eerste fase is die behoefies, begeertes en verwagtinge van die psigiatriese verpleegkundiges in ' $n$ hospitaal-verpleegdiens verken en beskryf. In fase twee is die faktore in 'n verpleegdiens wat die gehalte-werklewe van psigiatriese verpleegkundiges moontlik kan beïnvloed, verken en beskryf. Die studie is afgesluit met fase drie, die inferensiëring van data wat gelei het tot die beskrywing van die konseptuele raamwerk waarop die riglyne en program vir die fasilitering van gehaltewerklewe, gebaseer is. in Drieledige persoonlike en professionele ontwikkelingsprogram vir psigiatriese verpleegkundiges om gehalte-werklewe te fasiliteer, is beskryfom aspekte van die psigiatriese verpleegkundige se inteme omgewing, die eksteme omgewing, asook interaksiepatrone tussen die interne en eksteme omgewings in te sluit.

\section{INLEIDING}

Die verpleegdiensbestuurder is aanspreeklik vir die gehaltebestuur van ' $n$ verpleegdiens, waarvan personeelbestuur in belangrike komponent van die bestuursverantwoordelikheid vorm. Personeelbestuur bestaan uit vyf komponente, naamlik die voorsiening, benutting, besoldiging, ontwikkeling/opleiding en die behoud van personeel. Ten einde personeel in 'n verpleegdiens te behou, is een van die verpleegdiensbestuurders se verant-woordelikhede om gehalte-werklewe van verpleegkundiges te fasiliteer.

Die Verplegingsteorie vir Mensheelheid, wat gegrond is op ' $n$ Judeo-Christenfilosofie, vorm die teoretiese raamwerk van hierdie studie. Die verpleegkundige is " $n$ geestelike wese wat op ' $n$ geintegreerde biospigososiale wyse funksioneer (Oral Roberts University, 1990).
Psigiatriese verpleegkundiges se gehaltewerklewe word deur interne sowel as eksteme omgewingsfaktore beinvloed. ' $n$ Beraming van die unieke, kenmerkende interaksiewyses van die verpleegkundige met haar/sy eksterne omgewing, lei tot die identifisering van die behoeftes en struikelblokke wat die psigiatriese verpleegkundige se gesondheidstatus (in hierdie

Die navorsers glo dat die ontwikkeling en implementering $\operatorname{van}$ ' $n$ vertrouenswaardige persoonlike en professionele ontwikkelingsprogram, die gehalte-werklewe van psigiatriese verpleegkundiges behoort te fasiliteer. Hierdie artikel fokus op die ontwikkeling van sodanige program, met toepaslike riglyne. Die volgende navorsingsvrae is tersaaklik:

* wat is die psigiatriese verpleegkundiges, binne die konteks van 'n spesifieke studie gefokus op gehalte-werklewe) beïnvloed. hospitaal-verpleegdiens, se behoeftes, begeertes en verwagtinge om sin en betekenis (gehalte-werklewe) binne haar/sy werksomgewing te verwesenlik?

* watter faktore in 'n verpleegdiens beïnvloed die gehalte-werklewe van psigiatriese verpleegkundiges in ' $n$ spesifieke hospitaal?

* watter riglyne kan daargestel word vir ' $n$ persoonlike en professionele ontwikkelingsprogram om gehalte-werklewe van psigiatriese verpleegkundiges in ' $n$ hospitaal te fasiliteer?

Die doelstelling met hierdie navorsing was om riglyne te beskryf vir ' $n$ persoonlike en professionele ontwikkelingsprogram vir die fasilitering van psigiatriese verpleegkundiges se gehalte-werklewe in ' $n$ psigiatriese hospitaal. Ten einde ' $n$ konseptuele raamwerk vir hierdie riglyne te genereer, is die volgende twee doelwitte eers verantwoord:

Die verkenning en beskrywing van die behoeftes, begeertes en verwagtinge van psigiatriese verpleegkundiges in ' $n$ verpleegdiens ten einde gehaltewerklewe te fasiliteer. Die verkenning en beskrywing van faktore in ' $n$ verpleegdiens wat gehalte-werklewe van psigiatriese verpleegkundiges beïnvloed.

\section{TERMINOLOGIE}

\section{Gehalte-werklewe}

Gehalte-werklewe is die ervaring van sin en betekenis deur die psigiatriese verpleegkundige vanuit haar/sy unieke persoonlike behoeftes, begeertes en verwagtinge in die werksomgewing.

Persoonlike en professionele ontwikkelingsprogram

Dit is ' $n$ gestruktureerde program vir voortgesette persoonlike en professionele ontwikkeling van die psigiatriese verpleegkundige wat op ' $n$ wetenskaplike wyse ontwerp word en gerig is op die fasilitering van die psigiatriese verpleegkundige se gehalte-werklewe in 'n psigiatriese hospitaal. Die program bestaan uit riglyne vir die eksteme omgewing (" $n$ konteks bevorderlik vir gehalte-werklewe), in ver- 
rykingsprogram vir die psigiatriese verpleegkundige, asook ' $n$ toesighouerskursus vir die verpleegdiensbestuurders.

\section{NAVORSINGSONTWERP}

' $n$ Verkennende en beskrywende navorsingsontwerp, met ' $n$ kwalitatiewe navorsingsorièntasie, is nagevolg. Die studie is uitgevoer binne kontekstuele verband van die psigiatriese navorsingshospitaal en riglyne vir die persoonlike en professionele ontwikkelingsprogram wat uit die data geïnferensieer is, is dus nie veralgemeenbaar nie, maar geldig binne die konteks van die spesifieke hospitaal, met moontlike oordraagbaarheid na ander psigiatriese hospitale of verpleegdienste.

Die studie is in drie fases verdeel. In fase een is die behoeftes, begeertes en verwagtinge van psigiatriese verpleegkundiges verken en beskryf. Data-insameling het geskied aan die hand van tien individuele, semi-gestruktureerde onderhoudvoering met psigiatriese verpleegkundiges werksaam in die navorsingshospitaal. Die semi-gestruktureerde vraag was soos volg: Beskryf $u$ eie behoeftes, begeertes en verwagtinge om gehalte-werklewe -dit is werkstevredenheid - in u werk moontlik te maak.

'n Teoretiese, ewekansig-gestratifiseerde steekproefneming is gedoen om verteenwoordigend van die teikenpopulasie, naamlik Professionele Verpleegkundiges, Senior-verpleegkundiges en Hoofverpleegkundiges in die navorsingshospitaal te wees. "n Totaal van tien onderhoude is gevoer. Die een onderhoud is nie vir gesamentlike data-analise gebruik nie - die deelnemer het vanuit ' $n$ bestuursperspektief die vraag beantwoord en op haar verwagtinge van die ondergeskiktes gefokus.

Data-analise het geskied deur gebruik te maak van Kerlinger (1986:479-480) se metode van inhoudsanalise. Universele kategorieë, gebaseer op die behoeftes, begeertes en verwagtinge van die psigiatriese verpleegkundiges, is geïdentifiseer. Hierna is sub-kategorieë geïdentifiseer en verhoudings tussen kategorieë is vasgestel alvorens die finale klassifisering van hooftemas en konsepte vir die ontwikkeling van die konseptuele raamwerk gedoen is.

Geldigheid en betroubaarheid is verseker deur die toepassing van Woods en Catanzaro (1988:136-138) se riglyne vir kwalitatiewe navorsing. Toepaslike beheermaatreëls, in samewerking met ' $\mathrm{n}$ eksterne navorser, is streng toegepas om enige vorm van sydigheid uit te skakel.

In fase twee is die faktore in 'n verpleegdiens wat moontlik die gehalte-werklewe van psigiatriese verpleegkundiges kan beïnvloed, met behulp van die literatuurkontrole verken en beskryf. In hierdie fase van die navorsing is van denkstrategieë gebruik gemaak, naamlik analise en sintese om ' $n$ teoretiese verskynselanalise as navorsingsmetode te laat realiseer. Ooreenkomste en verskille tussen die empiriese werklikheid (resultate verkry vanuit die onderhoudvoering) en die literatuur is uitgelig. Geen doelbewuste seleksie van teoretiese bronne is gedoen nie. Interpretasie van data het geskied aan die hand van die hoof- en subkategorieë wat met die inhoudsanalise van die getranskribeerde onderhoude geïdentifiseer is.

Die studie is afgesluit met fase drie wat die finale beskrywing van die riglyne vir 'n persoonlike en professionele ontwikkelingsprogram om gehaltewerklewe van psigiatriese verpleegkundiges te fasiliteer. Inferensiëring van data vanuit die eerste twee fases van die studie het gelei tot die ontwikkeling van ' $n$ konseptuele raamwerk waarop die riglyne baseer is.

\section{RESULTATE}

Die psigiatriese verpleegkundige se behoeftes, begeertes en verwagting met betrekking tot die ervaring van gehalte-werklewe in "n hospitaal (interne omgewing) kom tot realisering in die eksterne omgewing - in haar eksterne leefomgewing, beroepsuitlewing en verhouding tot ander. Die hoof- en subkategoriee wat geidentifiseer is, word in tabel een uiteengesit.

Die inteme omgewing van die psigiatriese verpleegkundige sluit in die liggaamlike (anatomies/fisiologies), psigiese (intellek, emosies en wil) asook die geestelike aspekte (verhoudings) in. Met betrekking tot die liggaamlik aspekte het die psigiatriese verpleegkundiges ' $\mathrm{n}$ behoefte aan genoegsame rus en slaap uitgelig. Hierdie aspek van gehalte-werklewe is in die literatuur wat oor motivering handel bevestig. Die psigiese aspek verwys na drie komponente, naamlik intellek, emosies en wil. Met betrekking tot die psigiese dimensie het dit duidelik geblyk dat die psigiatriese verpleegkundige ondersteuning benodig vir die hantering van stresvolle werksomstandighede. Ander aspekte wat die verpleegkundige se ervaring van gehaltewerklewe beïnvloed, is onder andere die personeelevalueringstelsel, beroepsuitlewing (professionele identiteit, terapeutiese saalstruktuur, voortgesette ontwikkeling, transkulturele sensitiwiteit en tyd), asook erkenning, ondersteuning en ' $n$ behoefte om gehoor te word.

Gevoelens van tevredenheid, frustrasie, moegheid, ongelukkigheid, vernedering, demotivering en angs is uitgelig. Die verpleegkundige se motiveringsvlak blyk ' $n$ probleem te wees en ' $n$ behoefte aan toekomsgerigtheid en toereikende probleemoplossing is uitgespreek. In die geestelike aspek is daar in hierdie studie verwys na die psigiatriese verpleegkundige se verhouding to die self, dit wil sê ' $n$ positiewe selfbeeld en eie-waarde wat haar/sy gehalte-werklewe beïnvloed.

In die eksterne omgewing is verskeie behoeftes eise en verwagtinge beklemtoon om die ervaring van gehalte-werklewe moontlik te maak. Die fisieke eksterne omgewing verteenwoordig die eksteme leefwêreld binne die verpleegdiens, fisieke hulpbronne en die ekonomiese status van die psigiatriese verpleegkundige. Uit die resultate het dit geblyk dat die psigiatriese verpleegkundige groot klem plaas op die eksterne werksomgewing, veral ten opsigte van personeeltoekenning, die fisieke fasiliteite en toenusting asook regverdige personeelevaluering. Hulle verwag dat daar genoegsame personeel toegeken word en dat fisiese fasiliteite vir die versorging en hantering van pasiënte beskikbaar moet wees ten einde te verseker dat ' $n$ veilige, terapeutiese milieu vir sowel personeel as pasiënte gehandhaaf word. Die belangrikheid van veilige en bevredigende werksomstandighede is ook deur die literatuur as ' $n$ dimensie van gehaite-werklewe bevestig (Gerber, Nel \& van Dyk, 1992:426).

Voorgeskrewe uniforms blyk ' $n$ belangrike faktor te wees in die bevordering van gehalte-werklewe. Hoewel uniforms volgens Huston en Marquis (1989:327) bydra tot die estetiese en professionele beeld van die psigiatriese verpleegkundige, het verpleegkundige steeds behoefte daaraan om haar/sy individualiteit in hierdie verband uit te leef.

Die gehalte van ondersteunende dienste tot die verpleging van pasiënte, byvoorbeeld sekuriteitsdienste, instandhoudingsdienste (toerusting en fasiliteite), asook die beskikbaarheid van saalklerke, het sterk na vore gekom.

Die personeelevalueringstelsel is deur agt van die deelnemers bevraagteken. Dit was veral die objektiwiteit en regverdigheid van die personeelevalueringsinstrument wat ter sprake gekom het. ' $n$ Regverdige en vertrouenswaardige personeelevalueringstelsel is dus belangrik vir die ervaring van gehalte-werklewe (Marriner-Tomey, 1992:335).

Nog ' $n$ aspek waarop klem geplaas is, is die vergoedingspakette van psigiatriese verpleegkundiges wat nie na wense is om die ervaring van gehalte-werklewe te bevorder nie. Byvoordele het geblyk ' $n$ belangrike behoefte te wees -dit was veral " $n$ vier-dag werksweek en kraamverlof wat ter sprake gekom het. Werksekerheid is as ' $n$ fundamentele menslike behoefte geidentifiseer wat noodsaaklik is om gehalte-werklewe van psigiatriese verpleegkundiges te fasiliteer.

Wat betref die beroepsuitlewing van psigiatriese verpleegkundiges, is die invloed van professionele identiteit op gehalte-werklewe beklemtoon. Hoewel een deelnemer aan die navorsing te kenne gegee het dat sy somtyds skaam is om te sê dat sy ' $n$ verpleegkundige is, het ander deelnemers laat blyk dat hulle juis bevrediging kry uit die feit dat hulle as vaardige professionele persone 'n diens aan die gemeenskap kan verrig. Die korrelasie tussen gehalte-werklewe en professionele identiteit word bevestig deur Kramer (1991:51): "We also saw a definite positive correlation between nurses' job satisfaction and the perceived hospital image and valuation of nursing." 


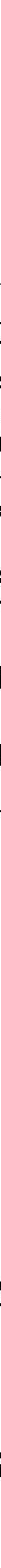




\section{Tabel 1}

Die behoeftes, begeertes en verwagtinge van psigiatriese verpleegkundiges met betrekking tot gehalte-werklewe binne die Verplegingsteorie vir Mensheelheid se eenheid van beraming en diagnosering

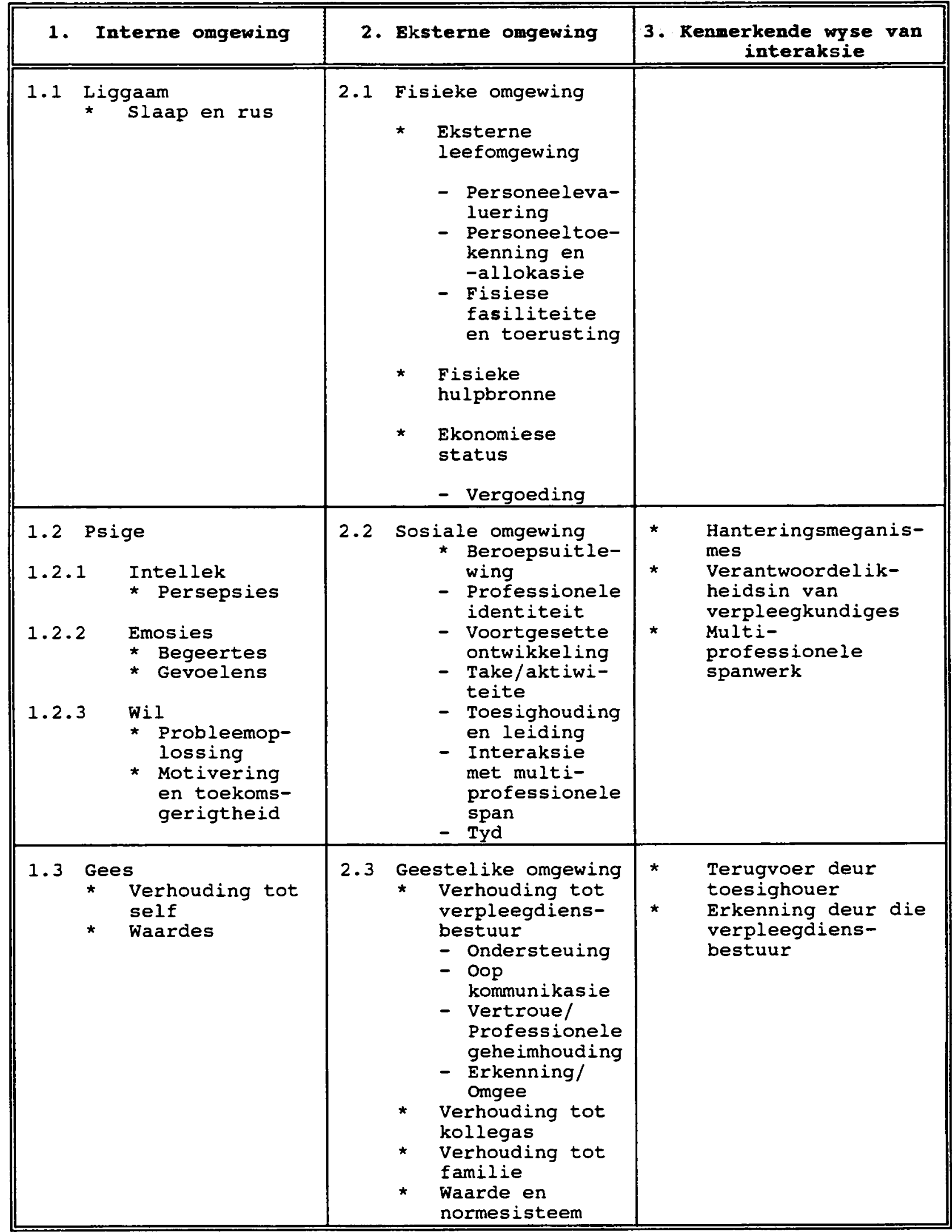


Die behoefte aan voortgesette ontwikkeling het ook sterk na vore gekom in sowel die onderhoude wat gevoer is as die literatuur wat bestudeer is. Die behoefte aan meer toepaslike indiensopleiding is in die onderhoude uitgespreek terwyl dit ook geblyk het dat heelwat psigiatriese verpleegkundiges in behoefte het aan voltydse/deeltydse studieverlof ten einde hulself beter te kwalifiseer. Dit het geblyk dat die huidige stelsel van studieverloftoekenning in die navorsingshospitaal onbevredigend ervaar word.

Psigiatriese verpleegkundiges se gehaltewerklewe word verder beïnvloed deur die take of aktiwiteite wat hulle verrig. Daar is ' $n$ behoefte aan uitdaging, verskeidenheid en verantwoordelikheid in die daaglikse werksuitlewing uitgespreek. Dit is duidelik dat direkte pasiëntsorg steeds die grootste bron van gehalte-werklewe van die psigiatriese verpleegkundige is -'n liefde vir die kliniese dienslewering. Hierteenoor het sommige deelnemers aan die navorsing frustrasie uitgespreek oor die hoeveelheid administratiewe en nie-verplegingstake wat hulle daagliks doen.

Psigiatriese verpleegkundiges het ' $n$ behoefte aan toesighouding en leiding in hul beroepsuitlewing. Ses van die deelnemers $(\mathrm{N}=9)$ het hierdie behoefte beklemtoon. Dit blyk asof daar ' $n$ sterk behoefte is aan "... managing by walking about ..." - die sogenaamde operasionele bestuur met kliniese kundigheid. Toesighouers wat derhalwe beskikbaar en toeganklik is behoort in betekenisvolle invloed op die ervaring van gehaltewerklewe by die psigiatriese verpleegkundige te hê.

Een van die aspekte in beroepsuitlewing wat besonder sterk in die resultate figureer, was die psigiatriese verpleegkundige se negatiewe persepsie teenoor tyd vir pasiëntsorg: "Daar is net nie genoeg tyd vir al die werk nie." Verder is die deelnemers van mening dat die aard van die werk te stresvol is en verbaliseer hulle ' $n$ behoefte aan ' $n$ vierdag-werkweek om sodoende ' $n$ meer gebalanseerde lewe te kan lei.
Die geestelike eksterne omgewing verteenwoordig die psigiatriese verpleegkundige se verhoudinge tot ander - die verpleegdiensbestuurder, kollegas en familie - asook die waardes en normsisteem van die beroep soos vervat in wetgewing, etiese kodes en teleid. Die aspek wat geblyk het die belangrikste invloed op psigiatriese verpleegkundiges se gehaltewerklewe in hierdie dimensie het, is die verhouding teenoor verpleegdiensbestuur. Daar het veral ' $n$ sterk behoefte na ondersteuning deur die verpleegdiensbestuurder na vore gekom, tesame met ' $n$ behoefte na beter kommuni-kasiekanale, in professionele vertrouens- verhouding in die werksopset, asook 'n meer versorgingsingesteldheid deur die verpleeg- diensbestuurder: "We need a more caring attitude from management."

Volgens die hteratuur wat geraadpleeg is, sluit hierdie verhouding ook aspekte in soos begrip, wedersydse vertroue, sensitiwiteit vir andere, erkenning, ondersteuning, oop kommunikasie, rolmodellering en situasionele of gebeurlik-

\section{Tabel 2 \\ Verrykingsprogram vir psigiatriese verpleegkundiges om gehalte-werklewe te fasiliteer}

\begin{tabular}{|ll||}
\hline MODULE EEN: & $\begin{array}{l}\text { Teoretiese raamwerk vir persoonlike en } \\
\text { professionele ontwikkeling vir gehalte-werklewe }\end{array}$ \\
\hline \hline $\begin{array}{l}\text { Konseptuele raamwerk van die Verplegingsteorie vir } \\
\text { Mensheelheid. }\end{array}$ \\
\hline
\end{tabular}

\begin{tabular}{|l||}
\hline MODULE TWEE: Selfkennis en selfbeeldverryking \\
\hline * Selfwaarneming/selfkennis \\
* Selfbeeldbou \\
* Selfmotivering \\
* Waarde-uitklaring \\
* Persoonlike lewensfilosofie \\
* Selfhandhawing \\
\hline
\end{tabular}

\section{MODULE DRIE: Streshantering}

* Identifisering van stresfaktore in die interne en eksterne omgewing

* Verbeteringsplan vir ondersteuningsnetwerke

* Kognitiewe rekonstruksie

* Probleemoplossingstrategieë

* Effektiewe tydsbestuur

\begin{tabular}{|l||}
\hline MODULE VIER: Aspekte van Eenheidsbestuur \\
\hline * Daarstelling en handhawing van 'n terapeutiese milieu \\
* Transkulturele sensitiwiteit \\
* Personeelevaluering \\
\hline
\end{tabular}


heidsleierskap. Kollegiale verhoudinge en die vermoë om as "n span te funksioneer, het 'n bepalende invloed op gehalte-werklewe. Hierdie aspek is deur al die deelnemers bevestig en dit het geblyk asook dit veral die ondersteuning is wat psigiatriese verpleeg-kundiges aan mekaar bied wat ' $n$ sterk behoefte is om gehalte-werklewe optimaal te laat realiseer. Begrip deur die familie en gesinslede is ook beklemtoon. "Verpleging eis baie van jou en jou familie moet dit kan verstaan."

Konstitusionalisering van die werksomgewing behels die reg tot privaatheid, vryheid van spraak en die beskerming van alle regte van die individu (Gerber et al., 1992:369). Die norme en waardesisteem van die gesondheidsorganisasie wat hierdeur tot uiting kom, beïnvloed die gehalte-werklewe van die psigiatriese verpleegkundige.

Interaksie tussen die interne en eksterne omgewing is ' $n$ belangrike aspek met betrekking tot hanteringsmeganismes, erkenning deur die verpleegdiensbestuurder wat lei tot verhoogde motivering, die verantwoordelikheidsin van psigiatriese verpleegkundiges en multiprofessionele spanwerk. Terselfdertyd het dit geblyk dat die deelnemers respek het vir 'n toesighouer wat op ' $n$ volwasse en positiewe wyse hulle op foute en tekortkominge kan wys en die nodige leiding vir korrektiewe aksies bied.

\section{KONSEPTUELE RAAMWERK VIR DIE FASILITERING VAN \\ GEHALTE-WERKLEWE BY DIE PSIGLATRIESE VERPLEEGKUNDIGE}

'n Konseptuele raamwerk is opgestel, gebaseer op die resultate wat vanuit die onderhoud- voering verkry is, asook 'n literatuurkontrole. Slegs ' $n$ grafiese voorstelling van hierdie konseptuele raamwerk word gebied (sien figuur een).

\section{RIGLYNE VIR 'N PERSOONLIKE EN PROFESSIONELE ONTWIKKELINGSPROGRAM VIR PSIGIATRIESE VERPLEEGKUNDIGES OM GEHALTE-WERKLEWE TE \\ FASILITEER}

'n Drie-ledige persoonlike en professionele ontwikkelingsprogram vir psigiatriese verpleegkundiges om gehalte-werklewe te fasiliteer is beskryf ten einde aspekte van die interne en eksterne omgewing in te sluit, asook interkasiewyses tussen die psigiatriese verpleegkundige se interne en eksteme omgewings. Die riglyne is nie voorskrywend van aard nie, maar is bedoel vir oorweging as moontlike alternatiewe met die oog op implementering wat volgens behoefte aangepas kan word.

\section{Riglyne vir die eksterne omgewing om gehalte-werklewe van psigiatriese verpleegkundiges te fasiliteer}

Sewe riglyne wat op die eksterne omgewing fokus is opgestel, met die operasionele implikasies van elkeen uitgelig.
Riglyn een

Skep 'n eksterne fisieke omgewing binne die psigiatriese verpleegdiens wat bevorderlik is vir die interaksie van die psigiatriese verpleegkundige in haar/sy strewe na gehalte-werklewe.

Operasionele implikasies: aandag behoort aan die volgende aspekte geskenk te word:

* Die skep van ' $n$ terapeutiese omgewing binne die verpleegdiens waar die veiligheid van pasiënte en personeel bevorder word.

* Die beskikbaarstelling van toepaslike ontspannings-fasiliteite vir die psigiatriese verpleegkundiges.

* Die verskaffing van uniforms met die instelling van 'n subsidiëringstelsel om voorsiening vir buigsaamheid te maak.

* Die beskikbaarstelling van alternatiewe vervoer om personeel wat vervoerprobleme het te help.

* Daar ontwikkeling en implementering van 'n meer vertrouenswaardige personeelevalueringstelsel, wat op die kliniese funksionering van die psigiatriese verpleegkundige fokus.

\section{Riglyn twee}

Die beskikbaarstelling en mobilisering van fisieke hulpbronne om gehalte-werklewe by die psigiatriese verpleegkundige te fasiliteer.

Operasionele implikasies:

* Die handhawing van ' $n$ terapeutiese klimaat in die gesondheidsdiens deur die beskikbaarstelling van toepaslike sekuriteitsdienste, asook werke- en terreininstandhoudingsdienste.

* Die beskikbaarstelling van saalklerke om die administratiewe lading van die kliniese personeel te verlig.

* Die beskikbaarstelling van 24 uurversorgingsdienste vir psigiatriese verpleegkundiges se kinders om gesinsverantwoordelikhede te verlig terwyl die verpleegkundige aan diens is.

\section{Riglyn drie}

Bevorder die professionele identiteit en onafhanklik praktykvoering van die verpleegkundige, binne die wetlike en etiese beroepsraamwerk.

\section{Operasionele implikasies:}

* Die ontwikkeling, implementering en evaluering van werkverrykingsprogramme wat daarop gerig is om verskeidenheid, betekenis, onafhanklikheid en terugvoering aan psigiatriese verpleegkundiges in hul beroepsuitlewing te verhoog.

* Die implementering van ' $n$ deelnemende bestuurstyl en situasionele of gebeurlikheidsleierskap om onafhanklike funksionering van die psigiatriese verpleegkundige te verhoog en sodoende persoonlike en professionele groei te fasiliteer.

* Die implementering van doelwitbestuur tot op grondvlak sodat elke psigiatriese verpleegkundige tot persoonlike en professionele doelwitbereiking gelei kan word.

* Die benutting van kleingroepaktiwiteite, soos gehaltekringe, om interaktiewe besluitneming en probleemoplossing te bevorder.

* Die ontwikkeling, implementering en evaluering van 'n verrykingsprogram om die psigiatriese verpleegkundige in staat te stel om aan die eise van die verandering en verwagtinge van die verpleegdiens te voldoen, om sodoende gehalte-werklewe te fasiliteer.

\section{Riglyn vier}

Verseker aktiewe betrokkenheid van die psigiatriese verpleegkundige in haar/sy volgehoue persoonlike en professionele groei in haar strewe na gehalte-werklewe.

Operasionele implikasies:

* Die voorsiening van opleidingsgeriewe en die ontwikkeling, implementering en evaluering van toepaslike personeelontwikkelingsprogramme om persoonlike en professionele groei te fasiliteer.

* Die formulering en implementering van beleid ten opsigte van formele, voortgesette onderwys vir psigiatriese verpleegkundiges.

* Die ontwikkeling en implementering van ' $n$ formele loopbaan-beplanningsprogram vir die psigiatriese verpleegkundiges om werksekuriteit en gehalte-werklewe te fasiliteer.

\section{Riglyn vyf}

Organiseer kommunikasiestrukture binne die verpleegdiens en met ander departemente wat die psigiatriese verpleegkundige in staat stel tot sinvolle omgewingsinteraksie in haar/sy strewe na gehalte-werklewe.

\section{Operasionele implikasies:}

* Die ontwikkeling van toereikende kommunikasiestrukture wat bevorderlik is vir positiewe interaksie in die verpleegdiens.

* Die kommunikasiestrukture is dinamies om aan nuwe behoeftes en verwagtinge van die psigiatriese verpleegkundige te voldoen.

* Die daarstelling en optimale funksionering van gesamentlike multi-professionele komitees vir pasiëntbesprekings en behandeling.

Die daarstelling en instandhouding van kommunikasie-strukture om griewe in die verpleegdiens te voorkom. 


\section{Tabel 3}

\section{Toesighouerskursus vir die verpleegdiensbestuur om gehalte-werklewe van psigiatriese verpleegkandiges te fasiliteer}

\begin{tabular}{|ll||}
\hline MODULE EEN: & $\begin{array}{l}\text { Teoretiese raamwerk vir die persoonlike en } \\
\text { professionele ontwikkeling van psigiatriese } \\
\text { verpleegkundiges vir gehalte-werklewe }\end{array}$ \\
\hline * $\quad \begin{array}{l}\text { Konseptuele raamwerk van die Verplegingsteorie vir } \\
\text { Mensheelheid } \\
\text { Ontwikkeling van 'n persoonlike en diensfilosofie geskoei } \\
\text { op die Verplegingsteorie vir Mensheelheid }\end{array}$ \\
\hline
\end{tabular}

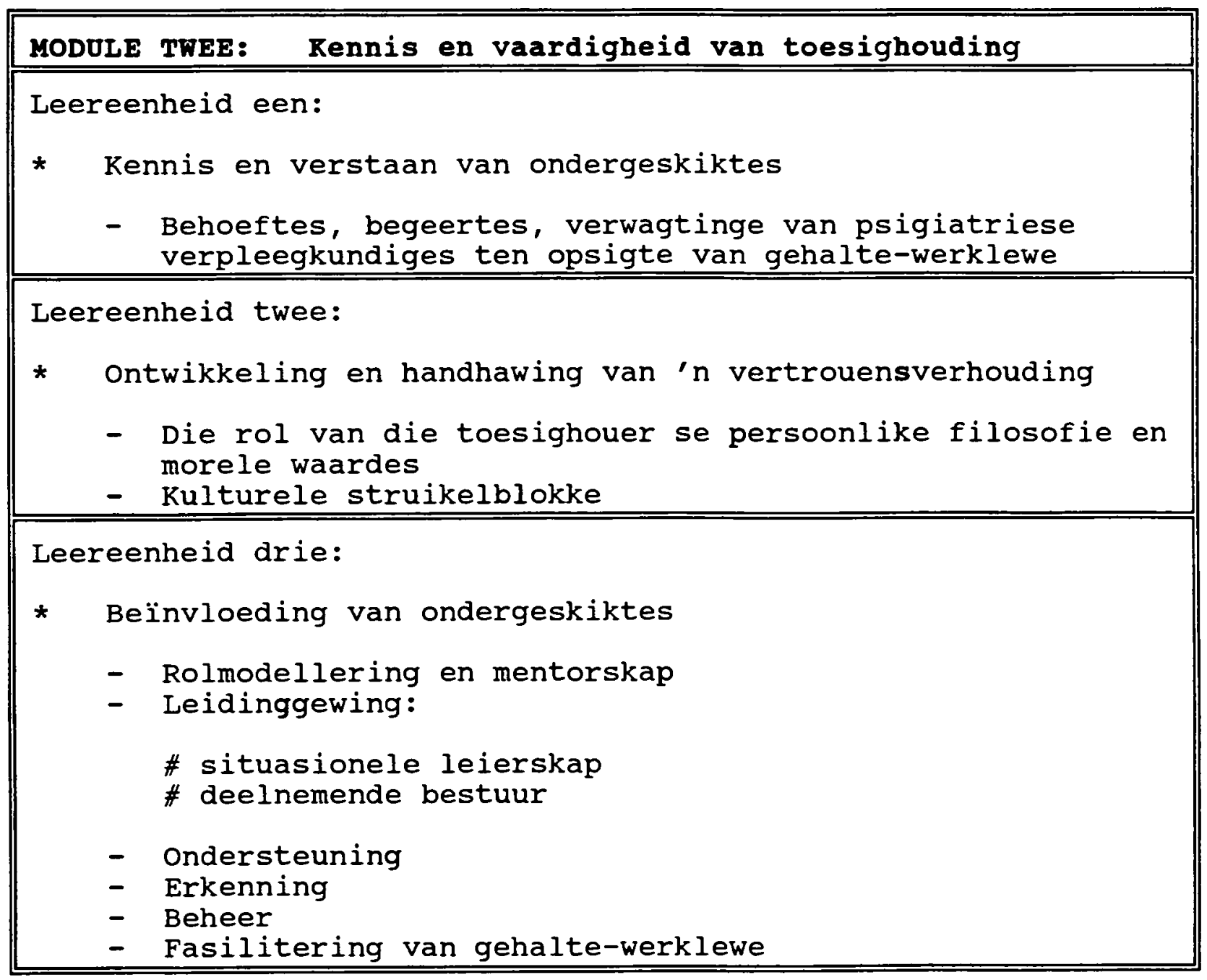

\section{MODULE DRIE: Personeelevaluering}

* Deurlopende evaluasie van personeel

- Doelwitstelling

- Terugvoering oor prestasie 
* Toepassing van die beginsels van toereikende arbeidsverhoudinge in die verpleegdiens om arbeidsvrede te fasiliteer.

\section{Riglyn ses}

Bevestig ' $n$ leiersklimaat wat bevorderlik is vir omgewingsinteraksie vir die psigiatriese verpleegkundige in haar/sy strewe na gehalte-werklewe.

\section{Operasionele implikasies:}

* Die ontwikkeling, implementering en evaluering van ' $n$ toesighouerskursus om leierskapsbeoefening te fasiliteer.

* Die toesighouers handhaaf die beginsels van effektiewe leierskapsbeoefening, met die fokus op situasionele of gebeurlikheidsleierskap.

* Erkenning van werksprestasies wat die psigiatriese verpleegkundige se motivering sal versterk en die leiersklimaat sal bevorder.

\section{Riglyn sewe}

Die handhawing van positiewe normes, waardes en standaarde in die verpleegdiens.

Operasionele implikasies:

* Gehalte-bestuur van die verpleegdiens, met ondersteuning deur die toesighouers.

* Die toepassing van die beginsels van deelnemende bestuur in die verpleegdiens om onafhanklike interaktiewe besluitneming en probleemoplossing deur psigiatriese verpleegkundiges te fasiliteer.

* Die ontwikkeling, implementering en evaluering van ' $n$ psigiatriese verpleegdiensstrategiese plan, opgestel in samewerking met die toesighouers, wat minstens op die volgende fokus:

- visie, missie en verpleegdiensfilosofie;

- strategiese doelwitte;

- operasionele planne waarvolgens doelbereiking kan plaasvind

- monitering van doelwitbereiking.

* Die ontwikkeling, implementering en evaluering van in gehalteverbeteringsprogram vir die verpleegdiens, waarvoor die psigiatriese verpleegkundige eienaarskap aanvaar.

* Die opstel en konsekwente implementering van beleid- en prosedurehandleidings om gehalteverpleging te fasiliteer.

* Die beskikbaarstelling en uitvoering van toepaslike wetgewing, regulasies en ander toepaslike makro-beleid.

* Die ontwikkeling en implementering van 'n professionele kode in die verpleegdiens, waarvoor die psigiatriese verpleegkundiges eienaarskap aanvaar.
Riglyne vir die interne omgewing om gehalte-werklewe van psigiatriese verpleegkundiges te fasiliteer

Die ontwikkeling, implementering en evaluering van 'n verrykingsprogram, gebaseer op die verpleegkundige se interne behoeftes, begeertes en verwagtinge (sien tabel twee).

* Die handhawing van die beginsels van interne motivering deur die psigiatriese verpleegkundige in haar/sy strewe na gehalte-werklewe.

Riglyne vir die interaksiewyses tussen die interne en eksterne omgewing om gehalte-werklewe by die psigiatriese verpleegkundige te fasiliteer

* Die handhawing van die beginsels van onvoorwaardelike aanvaarding, wedersydse respek, vertroue en sensitiwiteit tussen die bestuurders en kliniese verpleegkundiges in die verpleegdiens.

* Die ontwikkeling, implementering en evaluering van 'n toesighouerskursus, gerig op die daarstelling en instandhouding van positiewe verhoudinge in die verpleegdiens.

* Die handhawing van die beginsels van effektiewe personeelbestuur in die verpleegdiens om arbeidsvrede te handhaaf en gehalte-werklewe by die psigiatriese verpleegkundige te fasiliteer.

* Die fasilitering van gehalteverpleging deur die ontwikkeling en implementering van ' $n$ gehalteverbeteringsprogram in die verpleegdiens.

\section{SLOTOPMERKINGS EN AANBEVELINGS}

Die psigiatriese verpleegkundige se behoeftes, begeertes en verwagtinge om gehalte-werklewe in die verpleegdiens moontlik te maak, sentreer rondom die liggaamlike, psigiese en geestelike dimensies (interne omgewing), asook 'n eksterne omgewing (fisiek, sosiaal en geestelik) wat bevorderlik is vir die ervaring van sin en betekenis in die werksituasie.

In hierdie studie is ' $\mathrm{n}$ konseptuele raamwerk vir die fasilitering van gehalte-werklewe by die psigiatriese verpleegkundige, verken en beskryf. ' $n$ Induktiewe benadering is eerstens gevolg en semi-gestruktureerde onderhoude is met nege verpleegkundiges gevoer wat verteenwoordigend van die onderskeie kliniese afdelings in die navorsingshospitaal is. Die resultate is met die literatuur gekontroleer en verskeie riglyne vir die fasilitering van gehaltewerklewe by die psigiatriese verpleegkundige is beskryf. Die volgende aanbevelings word gemaak:

* Die implementering en evaluering van hierdie riglyne in die psigiatriese hospitaal.
* Die deregulering van staatsdiensbeleid sodat die verpleegkundiges onafhanklike fondsinsameling kan loods om die tekortkominge in veral die fisieke eksterne omgewing aan te spreek.

* Die ontwikkeling, implementering en evaluering van personeelontwikkelingsprogramme in psigiatriese hospitale, gebaseer op die riglyne.

* Die verkiesing van ' $n$ komitee in die verpleegdiens wat die verpleegkundige se vergoedings/diensvoorwaarde-behoeftes aan die verteenwoordigende beroepsorganisasie, vir onderhandelingsdoeleindes, bekendmaak.

* Die ontwikkeling van 'n model vir die fasilitering van gehalte-werklewe by verpleegkundiges.

* Die volgende hipoteses word vir toetsing gestel:

- Die implementering van deelnemende bestuur in ' $n$ verpleegdiens lei tot gehaite-werklewe by die verpleegkundige.

- Die toepassing van situasionele of gebeurlikheidsleierskap lei tot gehalte-werklewe by die verpleegkundige.

- Die eksteme fisieke omgewing beïnvloed gehalte-werklewe by die verpleegkundige.

- Die implementering van ' $n$ formele gehalteverbeteringsprogram in ' $n$ verpleegdiens bevorder gehaltewerklewe by die verpleegkundige.

Die verpleegdiensbestuurder fasiliteer gehaltewerklewe by die psigiatriese verpleegkundige deur voorsiening in die verpleegkundige (as werknemer) se liggaamlike/fisieke, psigies/ sosiaal en geestelike behoeftes, begeertes en verwagtinge. Sy behoort dus ' $n$ konteks te skep wat bevorderlik is vir die ervaring van sin en betekenis deur die verpleegkundige binne die verpleegdiens as werksomgewing.

\section{Erkennings en dankbetuigings}

Hiermee word opregte dank uitgespreek teenoor die verpleegdiensbestuur en psigiatriese verpleegkundiges wat aan hierdie studie deelgeneem het. Teresa Peens en Thelma van der Merwe word ook bedank vir hul deelname as onafhanklike navorsers.

\section{VERWYSINGS}

ANDREWS, Y (1985): Die personeelfunksie. Pretoria: HAUM.

BOTES, AC (1989): in Model vir wetenskapsbeofening in die Verpleegkunde. Johannesburg: Randse Afrikaanse Universiteit. 
BURNS, N \& GROVE, SK (1987): The practice of nursing research -conduct, critique and utilization. Philadelphia: WB Saunders.

DOUGLASS, LM (1992): The effective nurse, leader and manager; fourth edition. St Louis: Mosby.

FIELD, PA \& N MORSE, JM (1985): Nursing research. The application of qualitative approaches. London: Chapman \& Hall.

GERBER, PD; NEL, PS \& VAN DYK, PS (1992): Mannekragbestuur; tweede uitgawe. Johannesburg: Southem Uitgewers.

GILLIES, DA (1989): Nursing management: a systems approach. Philadelphia: WB Saunders.

HUSTON, CJ \& MARQUIS, BL (1989): Retention and productivity: strategies for nurse managers. Philadelphia: Lippencott.

KERLINGER, FN (1986): Foundations of behavioural research; third edition. New York: Holt, Rinehart \& Winston

KRAMER, M \& SCHMALENBERG, H (1988): Magnet hospitals: part 1 -institutions of excellence. Journal of Nursing Administration, 18(1), 13-24.
KRAMER, M (1991): Job satisfaction and retention - insights for the 90's. Nursing Research, 21(3) 50-55.

MARRINER-TOMEY, A (1992): Guide to nursing management; fourth edition. St Louis: Mosby.

MULLER, ME \& COETZEE, (1990): Verslag oor die ondersoek na die verpleegberoep. Pretoria: Suid-Afrikaanse Verpleegstersvereniging.

ORAL ROBERTS UNTVERSITY ANNA VAUGHN SCHOOL OF NURSING (1990): Self study report, submitted to the council of Baccalaureate and Higher Degree Programs, National League of Nursing Vol.1 (Aug) Narrative by Criteria. Tulsa, Oklahoma: Oral Roberts University Anna Vaughn School of Nursing.

RANDSE AFRIKAANSE UNTVERSITEIT, DEPARTEMENT VERPLEEGKUNDE (1992): Verplegingsteorie vir Mensheelheid. Johannesburg: RAU.

WOODS, NF \& CATANZARO, M (1988): Nursing research - theory and practice. Washington: Mosby.

VOGT, JF; VELTHOUSE, BA; COX, JL \& THAMES, BH (1983): Retaining professional nurses - a planned process. St Louis: Mosby.

\section{Beaulah Schoorwinkel}

M.Cur. Randse Afrikaanse Universiteit

Marie Muller

Professor: Departement Verpleegkunde Randse Afrikaanse Universiteit

Hester Klopper

Lektor: Departement Verpleegkunde Randse Afrikaanse Universiteit 